\title{
Guiding Neuronal Cell Migrations
}

\author{
Oscar Marín ${ }^{1}$, Manuel Valiente ${ }^{1}$, Xuecai Ge ${ }^{2}$, and Li-Huei Tsai ${ }^{2}$ \\ ${ }^{1}$ Instituto de Neurociencias, Consejo Superior de Investigaciones Científicas and Universidad Miguel \\ Hernández, Sant Joan d'Alacant 03550, Spain \\ ${ }^{2}$ Picower Institute for Learning and Memory, Department of Brain and Cognitive Sciences and Howard Hughes \\ Medical Institute, Massachusetts Institute of Technology, Cambridge, Massachusetts 02139 \\ Correspondence: o.marin@umh.es and Ihtsai@mit.edu
}

\begin{abstract}
Neuronal migration is, along with axon guidance, one of the fundamental mechanisms underlying the wiring of the brain. As other organs, the nervous system has acquired the ability to grow both in size and complexity by using migration as a strategy to position cell types from different origins into specific coordinates, allowing for the generation of brain circuitries. Guidance of migrating neurons shares many features with axon guidance, from the use of substrates to the specific cues regulating chemotaxis. There are, however, important differences in the cell biology of these two processes. The most evident case is nucleokinesis, which is an essential component of migration that needs to be integrated within the guidance of the cell. Perhaps more surprisingly, the cellular mechanisms underlying the response of the leading process of migrating cells to guidance cues might be different to those involved in growth cone steering, at least for some neuronal populations.
\end{abstract}

$T_{\mathrm{p}}^{\mathrm{h}}$ he migration of newly born neurons is a precisely regulated process that is critical for the development of brain architecture. Neurons arise from the proliferative epithelium that covers the ventricular space throughout the neural tube, an area named the ventricular zone (VZ). From there, newly born neurons adopt two main strategies to disperse throughout the central nervous system (CNS), designated as radial and tangential migration (Hatten 1999; Marín and Rubenstein 2003). During radial migration, neurons follow a trajectory that is perpendicular to the ventricular surface, moving alongside radial glial fibers expanding the thickness of the neural tube. In contrast, tangentially migrating neurons move in trajectories that are parallel to the ventricular surface and orthogonal to the radial glia palisade (Fig. 1). Besides their relative orientation, some of the basic mechanisms underlying the movement of cells using each of these two modes of migration are also different. For example, radially migrating neurons often use radial glial fibers as substrate, whereas tangentially migrating neurons do not seem to require their support to migrate. Even so, neurons may alternate from radial to tangential movement and vice versa during the course of their migration. This suggests that both types of migrations share common principles, in particular those directly

Editors: Marc Tessier-Lavigne and Alex L. Kolodkin

Additional Perspectives on Neuronal Guidance available at www.cshperspectives.org

Copyright (C) 2010 Cold Spring Harbor Laboratory Press; all rights reserved; doi: 10.1101/cshperspect.a001834

Cite this article as Cold Spring Harb Perspect Biol 2010;2:a001834 
O. Marín et al.
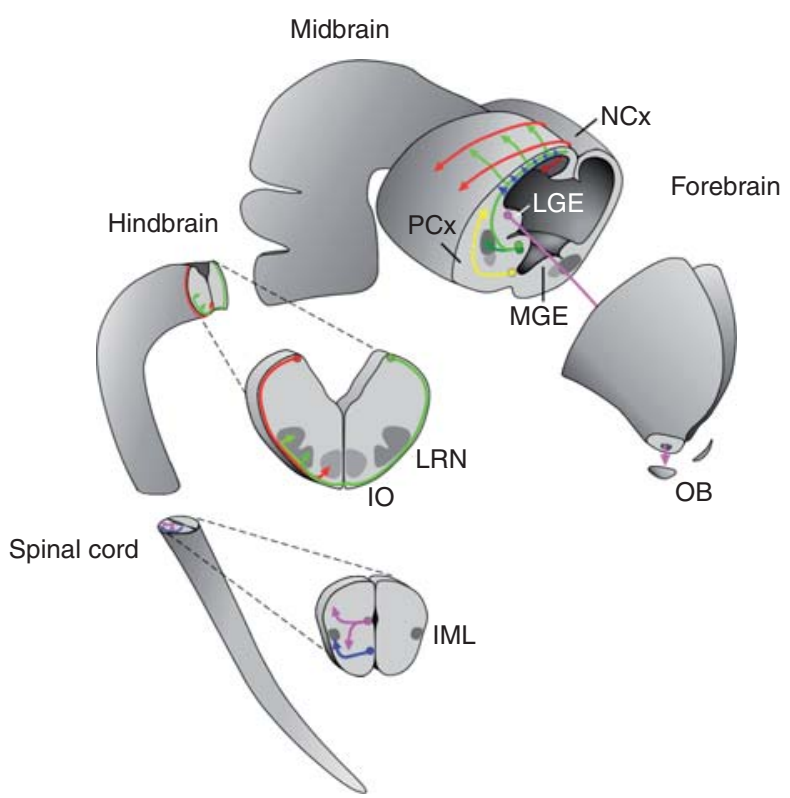

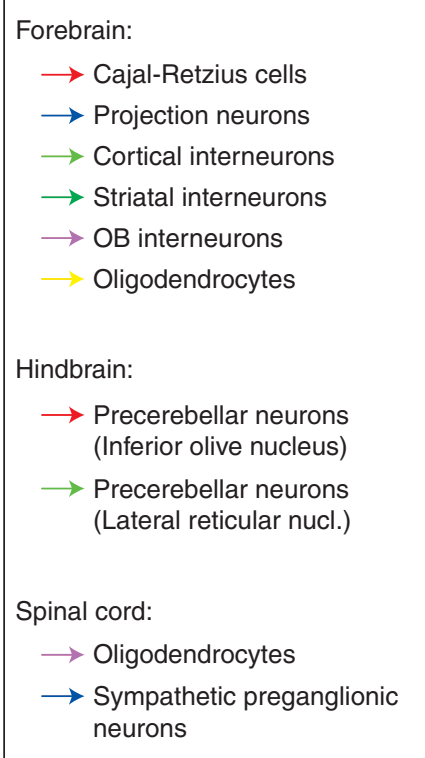

Figure 1. Representative migrations in the developing CNS. Multiple migrations coexist during embryonic development at different areas of the central nervous system. This schema summarizes some of these migrations during the second week of the embryonic period in the mouse. Neurons use tangential and radial migration to reach their final destination; both strategies are used by the same neurons at different stages of development (i.e., cortical interneurons in the forebrain and precerebellar neurons in the hindbrain). (IML) intermediolateral region of the spinal cord; (IO) inferior olive nucleus; (LGE) lateral ganglionic eminence; (LRN) lateral reticular nucleus; (MGE) medial ganglionic eminence; (NCx) neocortex; (OB) olfactory bulb.

related to the cell biology of movement (Marín et al. 2006).

One of the structures that better illustrates how both types of migrations are integrated during brain development is the cerebral cortex, and so we will primarily refer to studies performed on cortical neurons for this review. The adult cerebral cortex contains two main classes of neurons: glutamatergic cortical projection neurons (also known as pyramidal cells) and GABAergic interneurons. Pyramidal cells are generated in the ventricular zone (VZ) of the embryonic pallium - the roof of the telencephalon-and reach their final position by radial migration (Rakic 2007). In contrast, cortical interneurons are born in the subpallium-the base of telencephalon-and reach the cerebral cortex through a long tangential migration (Corbin et al. 2001; Marín and Rubenstein 2001).

The earliest cortical neurons form a transient structure known as the preplate, around embryonic day 10 (E10) of gestation age in the mouse. This primordial layer consists of Cajal-Retzius cells and the first cohort of pyramidal neurons, which will eventually populate the subplate. Cajal-Retzius cells, which play important roles during neuronal migration, arise from discrete pallial sources and colonize the entire surface of the cortex through tangential migration (Bielle et al. 2005; TakiguchiHayashi et al. 2004; Yoshida et al. 2006). The next cohort of pyramidal cells forms the cortical plate $(\mathrm{CP})$ by intercalating in the preplate and splitting this primitive structure in a superficial layer, the marginal zone (MZ or layer I), and a deep layer, the subplate. The development of the neocortex progresses with new waves of neurons that occupy progressively more superficial positions within the CP (Gupta et al. 2002; Marín and Rubenstein 2003). Birth dating studies have shown that layers II-VI of the cerebral cortex are generated in an "inside-out" sequence. Neurons generated earlier reside in deeper layers, whereas later-born neurons migrate past 
existing layers to form superficial layers (Angevine and Sidman 1961; Rakic 1974). In parallel to this process, GABAergic interneurons migrate to the cortex, where they disperse tangentially via highly stereotyped routes in the MZ, SP, and lower intermediate zone/ subventricular zone (IZ/SVZ) (Lavdas et al. 1999). Interneurons then switch from tangential to radial migration to adopt their final laminar position in the cerebral cortex (Ang et al. 2003; Polleux et al. 2002; Tanaka et al. 2003).

\section{CELLULAR MECHANISMS IN NEURONAL MIGRATION}

Migrating neurons are highly polarized in the direction of their movement. This is achieved through the generation, maintenance, and remodeling of a leading process that marks the direction followed by the cell. Leading processes are tipped by structures that are similar to the growth cones of migrating axons, and as such are thought to play an important role in sensing the surrounding microenvironment and thereby contributing to the guidance of neurons (Rakic 1990; Yee et al. 1999).

The standard movement of neurons is commonly known as locomotion (Nadarajah and Parnavelas 2002) (Fig. 2). Neurons undergoing locomotion follow three synchronized steps to move (Ayala et al. 2007; Marín and LópezBendito 2006). First, the cell extends a leading process. Second, the nucleus translocates into the leading process, a step referred to as nucleokinesis. Nucleokinesis typically occurs in a saltatory pattern, which suggests that nuclear movement is coupled to specific local dynamics in leading process. In the final step, the migrating neuron eliminates its trailing process, which leads to the net movement of the cell. The subsequent remodeling of the leading process will initiate a new migratory cycle, which will be repeated until the neuron reaches its final destination. It should be noted, however, that some neurons do not form a trailing process. Pyramidal cells, for instance, extend their axon as they move (Noctor et al. 2004; Schwartz et al. 1991).

The basic migratory cycle is simplified when the leading process reaches its destination, which happens during the last cycle of neurons undergoing locomotion or in early born pyramidal neurons. This later process, known as somal translocation, involves nucleokinesis and trailing process remodeling without the extension of additional leading processes (Miyata et al. 2001; Miyata and Ogawa 2007; Nadarajah and Parnavelas 2002).

\section{Leading Process Dynamics}

The leading process acts as the compass of migrating neurons, selecting the direction of migration in response to chemotactic cues. The leading process also reflects the state of polarization of migratory neurons, which in some cases may vary in different phases of the migration (Fig. 2). For example, newly born pyramidal cells have a single process as they leave the pallial VZ (Noctor et al. 2001), but they become transiently multipolar for a short period of time in the SVZ. During this phase, neurons partially generate several short processes oriented tangentially (Tabata and Nakajima 2003). Subsequently, pyramidal cells become highly polarized again and establish a leading process that remains in contact with radial glial fibers until they cease migration (Rakic 1972).

The morphology of the leading process varies in different neuronal types, probably reflecting an adaptation to different migratory requirements (Fig. 2). In cortical interneurons, for instance, the leading process branches as part of the migratory cycle (Bellion et al. 2005; Kappeler et al. 2006; Martini et al. 2009). This seems to be common to many tangentially migrating neurons (Okada et al. 2007). In contrast, radially migrating neurons seem to have a single leading process (Rakic 1972). Interestingly, defects in the interaction between pyramidal cells and radial glial fibers frequently lead to aberrant branching of the leading process (Elias et al. 2007; Gupta et al. 2003), which suggest that the bipolar morphology of radially migrating neurons might be imposed by glialguided locomotion.

Recent time-lapse experiments have shown how migrating neurons integrate the dynamic reorganization of branched leading processes 
O. Marín et al.

A

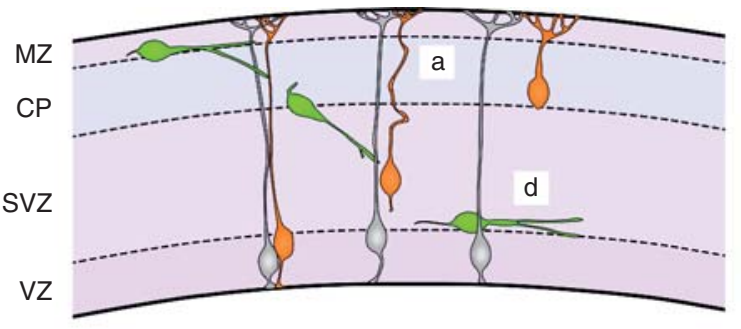

B

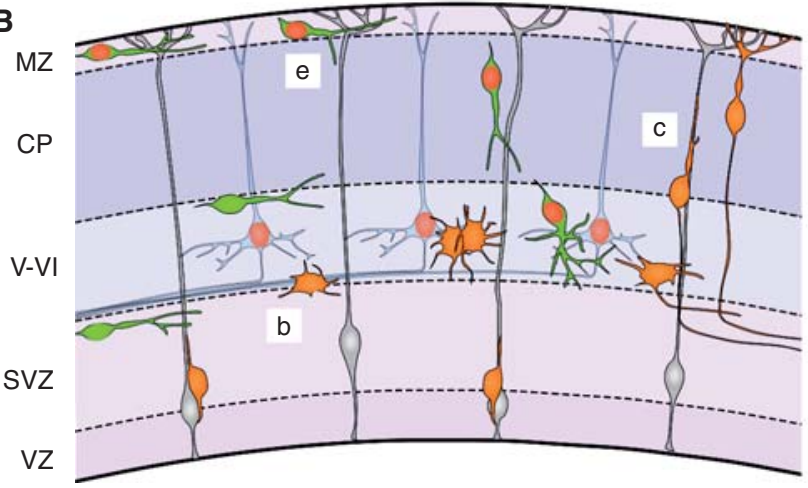

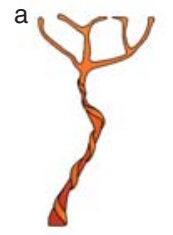

d

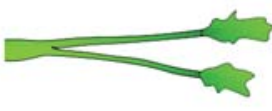

C

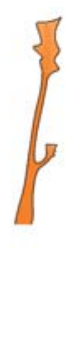

e

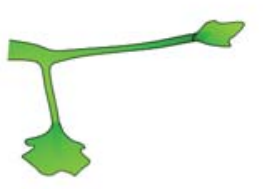

Figure 2. Leading process dynamics in cortical migrating neurons. (A) Early generated pyramidal cells migrate independently of radial glia fibers by translocating their soma toward the meninges using a springlike mechanism (a). (B) As the cerebral cortex grows, the distance between the ventricular zone (VZ) and the marginal zone (MZ) increases, and pyramidal cells use locomotion to reach the cortical plate (CP). Pyramidal cells go through a multipolar state (e) before attaching to the radial glial process and continue their migration toward the cortical plate $(c)$. Cortical interneurons initially migrate tangentially through the cortex in defined streams (A and B), without invading the cortical plate. Then, eventually, they move radially to allocate in a particular cortical layer. The leading process of these cells develops several branches, which are used to modify their trajectory ( $\mathrm{d}$ and e). Projection neurons and interneurons born at the same time end up occupying the same layers (red colored nuclei represent cells born at the same time). (SVZ) subventricular zone; (VZ) ventricular zone; (V-VI) cortical layers V and VI.

into the migratory cycle (Martini et al. 2009). In cortical interneurons, the two branches are oriented toward the front of the cell and have a dynamic, exploratory behavior until the cell decides what direction to follow. At this point, only one of the branches keeps extending, whereas the other begins retracting. This event is followed by nucleokinesis, in which the nucleus typically advances up to the previous branching point. These steps are repeated continuously with the generation of a new branch in the leading process in each migratory cycle.

The ability of tangentially migrating neurons to generate a branched leading process appears to be intimately linked to their guidance. In these cells, chemoattractants and chemorepellents induce the biased formation of new leading processes already oriented toward or against, respectively, the source of the guidance molecule (Martini et al. 2009; Ward et al. 2005). This seems to allow migrating neurons to rapidly change direction without having to reorient pre-existing branches. For example, interneurons invade the $\mathrm{CP}$ by generating new branches that are oriented orthogonally to their tangential migration (Martini et al. 2009; Polleux et al. 2002; Yokota et al. 2007). Interestingly, this guidance mechanism seems to be very different than that described for growing axons, in which growth cone steering determine the direction of movement (Lin and Holt 2007). In migrating cells with branched leading processes, the angle formed between branches remains relatively stable 
during each migratory cycle, and therefore the cell chooses the new direction out of two preexisting options, in a binary manner (Martini et al. 2009; Ward et al. 2005). It is presently unclear why navigating axons are able to orient up gradients of guidance cues using a single growth cone, whereas many migrating neurons have developed complicated leading process dynamics for guidance. One possible explanation is that the generation of multiple leading process branches represents a very efficient method for the exploration of the microenvironment (Britto et al. 2009).

Not all tangentially migrating neurons use this guidance mechanism to achieve directional migration. In some cellular contexts, the guidance of the leading process is remarkably similar to axon guidance. This is the case, for example, of pontine neurons, which generate a long leading process of up to a $1000 \mu \mathrm{m}$ that extends continuously toward the floor plate before nucleokinesis (Yee et al. 1999). In this form of somal translocation, growth cone steering seems to be responsible for the guidance of the migration, as it happens during axon guidance. It should be noted, however, that this does not seem to be the most common behavior for migrating neurons in the CNS.

Little is known about the molecular mechanisms regulating leading process dynamics in migrating neurons. CDK5, a serine/threonine cyclin-dependent kinase, modulates the extension of the leading process through phosphorylation of Pak1 and p27Kip1, two important actin regulators (Dhavan and Tsai 2001; Kawauchi et al. 2006a; Nikolic et al. 1998). Pak1 phosphorylation by CDK5 down-regulates Pak1 activity, thereby modulating the actin dynamics in the growth cone (Nikolic et al. 1998). On CDK5 phosphorylation, p27Kip1 is stabilized in neurons, and this stabilization is critical to keep the proper level of F-actins in the leading processes (Kawauchi et al. 2006b).

Lissencephaly 1 (Lis1) and Doublecortin (DCX), two microtubule associated proteins that are better known for their roles during nucleokinesis (see next section), are also involved in regulating leading process branching in migrating interneurons (Kappeler et al.
2006; Nasrallah et al. 2006). The leading process of $D c x$-deficient interneurons branches more frequently than normal, but new branches are very unstable. This suggests that DCX is required to stabilize new leading process branches, and that cytoskeleton instability in the leading process may prompt neurons to branch more frequently (Kappeler et al. 2006). In contrast, the leading process of interneurons heterozygous for a Lis1 mutation branch less frequently and, consequently, is longer than in normal cells (Nasrallah et al. 2006). These results suggest that Lis 1 is required for leading process branching, and ultimately, guidance of these neurons. Altogether, these evidences indicate that Lis1 and DCX play complementary roles in leading process dynamics.

\section{Nucleokinesis}

The translocation of the nucleus into the leading process is the mechanism that best defines neuronal migration (Fig. 3). Time-lapse imaging studies reveal that nucleokinesis occurs in two steps. First, a cytoplasmic swelling forms in the leading process, immediately proximal to the nucleus. The centrosome, which is normally positioned in front of the nucleus, moves into this swelling (Bellion et al. 2005; Schaar and McConnell 2005; Tsai and Gleeson 2005). The centrosome is accompanied by additional organelles, including the Golgi apparatus, mitochondria, and the rough endoplasmic reticulum. Second, the nucleus follows the centrosome. These two steps are repeated producing the typical saltatory movement of migrating neurons.

Nucleokinesis relies on a large interactive signaling network. According to the current model, forces generated within the leading process are transmitted to the centrosome, which moves forward. The centrosome is constantly linked to the nucleus through a microtubule network that envelops the nucleus in a "fork-" or "cage"-like structure (Rivas and Hatten 1995; Xie et al. 2003). Following centrosome movement, the nucleus is pulled toward it by dyneins associated with the microtubule network (Rivas and Hatten 1995; Solecki et al. 
O. Marín et al.

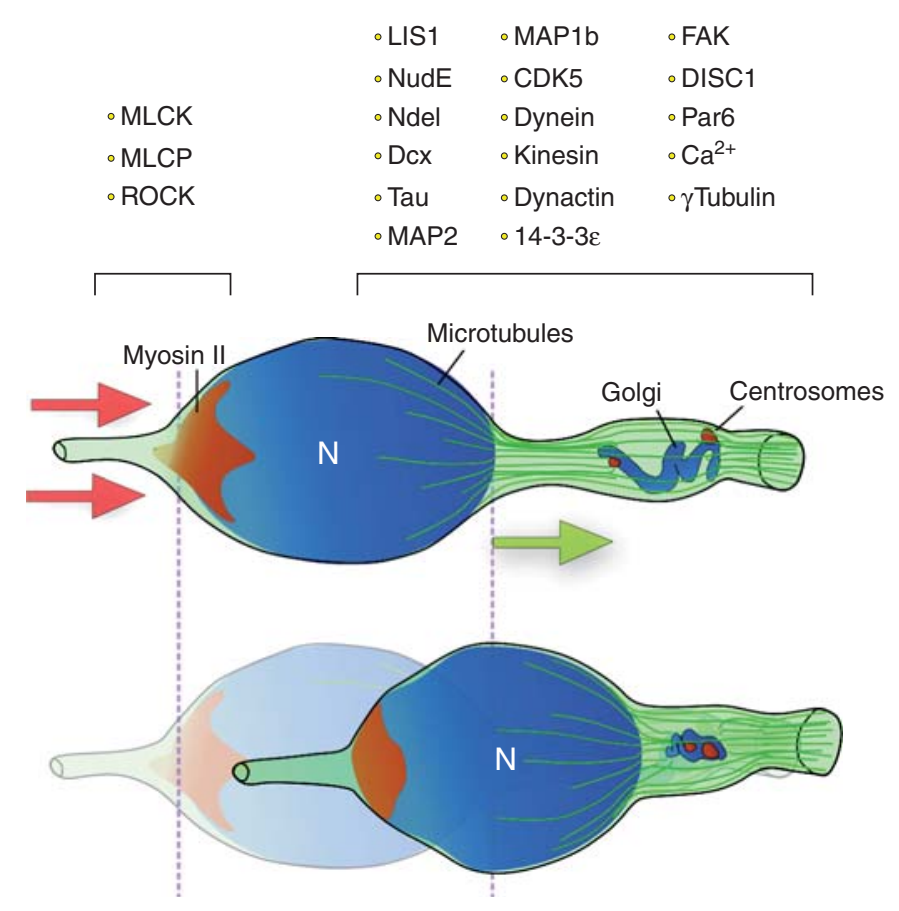

Figure 3. Nucleokinesis in migrating neurons. Nucleokinesis involves both perinuclear and nucleus translocation. First, the perinuclear dilatation containing the centrosome and the Golgi apparatus move forward. The perinuclear microtubular cage (in green) pulls the nucleus forward until reaching the swelling. Forward pulling forces (green arrow) are complemented by myosin II at the rear, which generates pushing forces (red arrows) to move the nucleus in its characteristic saltatory pattern of nucleokinesis. Many motor proteins and other proteins related to the cytoskeleton are implicated in the process. $(\mathrm{N})$ nucleus.

2004; Tsai and Gleeson 2005; Xie et al. 2003) (Fig. 3). In addition, actomyosin contraction in the rear of the cell contributes to drive the nucleus forward during nucleokinesis (Bellion et al. 2005; Schaar and McConnell 2005).

Our knowledge of the molecular mechanisms underlying nucleokinesis largely derives from studies on human neurological syndromes. For example, impaired neuronal migration causes a human brain malformation known as lissencephaly ("smooth brain"), characterized by an abnormally thickened cerebral cortex that lacks normal cerebral convolutions and organized layers (Francis et al. 2006; Jellinger and Rett 1976). Lissencephaly has been attributed to mutations in two genes, LIS1 and DCX. Mutations in LIS1 result in autosomal dominant lissencephaly (Hattori et al. 1994; Reiner et al. 1993), whereas mutations in DCX are responsible for X-linked lissencephaly in males and for a syndrome known as double cortex in females.
Double cortex is manifested as a subcortical band of neuronal cell bodies in the white matter, caused by the arrest of a population of neurons halfway between the ventricle and the cortex (des Portes et al. 1998; Gleeson et al. 1998).

Although the mouse cortex has no convolutions, mice deficient in Lis1, Dcx, or their interactive proteins have proven very valuable to understand human lissencephaly. Mice heterozygous for a Lis1 null allele display only mild defects in neuronal migration, but further reduction of Lis1 levels by combining a null allele with a hypomorphic Lis 1 allele profoundly disrupts cortical lamination (Gambello et al. 2003; Hirotsune et al. 1998). In many Lis1deficient neurons, the extension of the leading process is unaffected (but see McManus et al. 2004), suggesting that the perturbed neuronal migration most likely results from defects in nucleokinesis (Shu et al. 2004; Tanaka et al. 2004; Tsai and Gleeson 2005). 
Lis 1 associates with microtubules and a subpopulation of Lis1 localizes to the centrosome. It promotes microtubule stability by inhibiting microtubule catastrophe in vitro (Sapir et al. 1997). Interestingly, in filamentous fungi, Lis 1 belongs to a highly conserved family of genes that regulate nuclear migration, an event that is reminiscent of nucleokinesis in migrating neurons. This family also includes Ndel 1 and dynein (Morris et al. 1998). Ndel1 is required for targeting Lis1 and dynein to the centrosome, and facilitates the nucleation and anchoring of microtubules to the centrosome (Guo et al. 2006). In addition, Ndel1 facilitates the interaction between Lis1 and dynein and regulates dynein-mediated retrograde transport (Gupta et al. 2003; Li et al. 2005; Mesngon et al. 2006; Smith et al. 2000). Disruption of Lis1 function abolishes centrosomenucleus coupling, increasing the distance between the two organelles. Similar defects are observed in neurons with Ndell or dynein loss of function (Aumais et al. 2001; Dawe et al. 2001; Sasaki et al. 2000; Shu et al. 2004; Tsai et al. 2005), suggesting that Lis1, Ndel1, and dynein regulate the microtubule network that couples the centrosome to the nucleus. Perturbation of this complex may contribute to the cortical lamination defects observed in lissencephaly patients (Ayala et al. 2007; Higginbotham and Gleeson 2007; Tsai and Gleeson 2005).

Mice with $D c x$ mutations display no detectable defects in the cerebral cortex, and only mild abnormalities in the hippocampus (Deuel et al. 2006). One possible explanation is that genetically redundant pathways may compensate for the absence of DCX in the knockout mice. This possibility is supported by the observation that acute knockdown of DCX from rat cortex using RNAi results in severe defects in neuronal migration, with affected neurons aberrantly accumulated in the intermediate zone of the cortex (Bai et al. 2003). The compensative effect seems to be mediated by Doublecortin-like kinase (DCLK), a protein with great similarity to DCX (Burgess et al. 1999; Lin et al. 2000). DCX and DCLK are microtubule associate proteins, and both promote the polymerization and stabilization of the microtubules (Francis et al. 1999; Gleeson et al. 1999; Horesh et al.
1999). Similar to DCX, DCLK null mice show no lamination defects, whereas DCLK acute knockdown via RNAi disrupts neuronal migration (Koizumi et al. 2006). Further evidence of genetic redundancy of the two genes comes from DCX/DCLK double knockout mice. In these mice, radial migration is severely disrupted, and cortical layers are abnormally broad and less distinct (Deuel et al. 2006; Koizumi et al. 2006; Tanaka et al. 2006).

Increasing evidence indicates that DCX and DCLK participate in the regulation of nucleokinesis during neuronal migration. Interneurons lacking DCX have nucleokinesis abnormalities (Kappeler et al. 2006). In particular, the centrosome-containing cytoplasmic swelling can move backward toward the nucleus in $D c x$ mutant neurons, indicating a problem in the polarization of organelles in these cells. Consistently, knockdown of Dcx in pyramidal cells leads to an abnormally hyperactive centrosome, with loss of directional movement and lack of spatial correlation with the nucleus (Sapir et al. 2008). In addition, the centrosome-nucleus uncoupling observed in Lis1 or dynein-deficient cells is rescued by DCX expression (Tanaka et al. 2004). These results suggest that DCX and DCLK play important roles in the maintenance of the microtubule network coupling the centrosome and the nucleus in migrating neurons.

Studies on CDK5 and its activators p35 and p39 reveal another important signaling pathway involved in neuronal migration. Cdk5 null mice die around birth, and show widespread disruptions in neuronal layering of multiple cortical structures. In the cerebral cortex, the preplate is successfully split, but subsequently generated neurons fail to migrate past their predecessors, and are accumulated progressively into deeper layers, resulting in an inverted "outside-in" cortex (Gilmore et al. 1998; Ohshima et al. 1996). Mouse mutants for $p 35$ display inverted layering of cerebral cortex similar to $C d k 5$ knockouts, but only have mild abnormalities in the hippocampus and cerebellum (Chae et al. 1997; Kwon and Tsai 1998). Although p39-deficient mice do not show noticeable defects, the phenotype of $p 35 / p 39$ double mutant is indistinguishable from $C d k 5$ null mice (Ko et al. 2001). These 
results suggest an essential role of CDK5 and its activators in neuronal migration.

Several lines of evidence support the idea that CDK5 function is essential in nucleokinesis. First, Ndel1 contains five CDK5 phosphorylation sites, and the phosphorylation may modify the interaction between Ndell and Lis1/dynein. Hence, CDK5 may potentially regulate neuronal migration through modulating the function of Lis1/Ndel1/dynein complex, which has wellestablished roles in nucleokinesis. Second, CDK5 phosphorylates many microtubule-associated proteins, including the previously discussed DCX, MAP1b, and tau, and modulates their association with microtubules. For instance, CDK5 phosphorylation of DCX on Ser297 enhances its binding to microtubules. Abolishing this phosphorylation dissociates DCX from microtubules, which subsequently leads to microtubule depolymerization and ultimately defective migration (Tanaka et al. 2004). Third, CDK5 also phosphorylates other kinases, such as focal adhesion protein (FAK). Phosphorylation of FAK by Cdk5 at Ser732 is required for the organization of the perinuclear microtubule network. Inhibition of FAK Ser732 phosphorylation results in abnormal nuclear movement and laminar positioning defects in vivo (Xie et al. 2003). Collectively, these evidences suggest that CDK5 plays an essential role during nucleokinesis.

Although the function of Lis1, DCX, DCLK, and CDK5 in nucleokinesis has been primarily studied in radially migrating cells, analysis of other neuronal populations suggests that they play a universal role in this process (Friocourt et al. 2007; Kappeler et al. 2006; McManus et al. 2004; Nasrallah et al. 2006; Rakić et al. 2009).

\section{MECHANISMS AND CUES GUIDING RADIAL NEURONAL MIGRATIONS}

\section{Radial Glia-Neuron Interactions}

Radial glia cells play fundamental roles in neuronal migration. These cells, which are the progenitors of pyramidal cells (Noctor et al. 2001), have their cell bodies in the VZ and extend their long processes spanning the entire thickness of the developing cortex. As the thickness of the developing cortex grows, neurons undergoing locomotion use these fibers as a guide to reach the CP (Campbell and Gotz 2002; Rakic 1971). Various membrane-bound cell adhesion molecules, including astrotactin, neuregulin, and several integrins, mediate the interaction of migrating neurons and radial glial fibers (Adams et al. 2002; Anton et al. 1997; Edmondson et al. 1988; Fishell and Hatten 1991; Stitt and Hatten 1990). We will use the integrin family as an example to illustrate how membrane-bound cell adhesion molecules regulate radial migration.

Integrins are transmembrane receptors that mediate cell-cell and cell-extracellular matrix interactions. Functional integrins are composed of $\alpha$ and $\beta$ subunits that form heterodimers. Multiple $\alpha$ subunits are expressed in the developing cortex, including $\alpha 3, \alpha \mathrm{V}$, and $\alpha 6$, all of which dimerize with $\beta 1$ integrin. Mouse mutants for each of these integrin genes show distinct cortical lamination phenotypes, indicating that different subunits may play different roles in neuronal migration (Marín and Rubenstein 2003). Targeted mutation of $\alpha 3$ integrin results in retarded neuronal migration and disrupted cortical lamination (Schmid et al. 2004). Consistently, in vitro blocking $\alpha 3$ integrin reduces the migration speed and detaches migrating neurons from radial glia (Anton et al. 1999; Dulabon et al. 2000). Conditional knockout of $\alpha \mathrm{V}$ integrin in radial glia leads to extensive cerebral hemorrhage in embryos (Bader et al. 1998; McCarty et al. 2005), but this phenotype prevents a profound evaluation of cortical development. In $\alpha 6$ integrin null mice, ectopic clusters of cells penetrate the pial surface, and cortical lamination is disturbed. This overmigration of neurons has been attributed to persistent laminin deposits along radial glia fibers, which may prevent neurons from arresting their migration and localizing to the appropriate layer (Georges-Labouesse et al. 1998). Conditional knockdown of the $\beta 1$ subunit leads to disrupted cortical lamination as well. In these mice, the anchoring of radial glial end feet at the pial surface is perturbed, which may explain the observed neuronal positioning defects (Graus-Porta et al. 2001). These 
studies indicate a wide spectrum of cell adhesion functions mediated by the integrin family, which cooperatively modulate the radial migration of cortical neurons.

The signaling events downstream of the various integrins are not fully elucidated. However, several studies suggest that CDK5/P35, Filamin $A$, and Disabled-1 (Dab1) are involved in integrin-mediated signaling. $\alpha 1 \beta 1$ integrin activates CDK5 (Li et al. 2000), which interact with multiple proteins involved in the adjustment of the cytoskeleton. Filamin A, an actin cross-linking protein, binds to $\beta 1$ integrins (Loo et al. 1998). Filamin A mutations in humans cause periventricular heterotopia, a disease characterized by ectopic neuronal clusters lining the lateral ventricles beneath the cortical white matter (Sarkisian et al. 2008). Filamin A deficient mice display aberrant adherent junctions at the lining of the ventricular zone (Feng et al. 2006), which may be partially responsible for the failure of initiation of neuronal migration. Furthermore, in vitro studies showed that mutations in $\beta$ integrins, which increase their binding capacities with Filamin A, inhibits cell migration through blockage of the membrane protruding dynamics critical in early steps of neuronal migration (Calderwood et al. 2001). Hence, it is possible that in migrating neurons, Filamin A links extracellular signaling from integrins to the actin filament network at the leading edge of the migrating neuron (Sarkisian et al. 2008). Dab1, a tyrosine phosphorylated adaptor protein mediating Reelin signaling, also associates with the cytoplasmic region of $\beta 1$ integrin (Schmid et al. 2005). It is hypothesized that the interaction between $\alpha 3 \beta 1$ integrin with the Reelin signaling pathway may trigger the internalization of integrins, thus leading to the detachment of migrating neurons from the radial glial processes (Dulabon et al. 2000; Schmid et al. 2005). Together, these studies suggest that integrin activation is translated by intracellular mediators to modifications of the microtubule and actin networks as well as cell-cell adhesion, both of which are precisely modulated during neuronal migration.

Recent studies have shown that the interaction between radial glial fibers and migrating neurons also relies on the adhesive properties of Gap junctions (Cina et al. 2009; Elias et al. 2007). Several connexins, the component of Gap junctions, are expressed in both radial glial cells and migrating neurons, and their association in trans is required for glial-guided migration. Interestingly, the channel capabilities of Gap junctions are not required for this process. The mechanisms regulating the dynamic assembly and disassembly of these transient contacts between radial glial fibers and migrating neurons are currently unknown.

\section{Cues Regulating Radial Migration}

A large number of secreted extracellular molecules have been shown to regulate migration, including Slits, netrins, semaphorins, and Reelin (Fig. 4). The functions of Slits, netrins, and semaphorins have been characterized in tangential migration, but their role in radial migration is not as well studied as Reelin. Thus, we will use Reelin as an example to illustrate how extracellular molecules and their receptors regulate neuronal migration and positioning.

The discovery of the Reelin pathway originates from the reeler mouse, initially described over 50 years ago. These spontaneous mutant mice display abnormal behaviors such as ataxia, tremor, and reeling gaits, and their brains have layering defects in multiple brain regions, but most prominently in cortical areas (Lambert de Rouvroit and Goffinet 2001; Rice and Curran 1999). In the neocortex, the preplate forms normally, but the next cohort of cortical neurons fails to divide it into the marginal zone and the subplate. Moreover, birth dating experiments showed an inverted lamination pattern of the reeler cortex (Caviness 1982). Subsequent studies revealed that mutations in Reelin, a gene encoding for a large extracellular glycoprotein, is mutated in reeler mice (D'Arcangelo et al. 1995; Hirotsune et al. 1995; Ogawa et al. 1995; Sheppard and Pearlman 1997). Reelin is secreted by Cajal-Retzius cells located in the marginal zone, and it binds to two members of the lipoprotein family receptors, VLDLR and ApoER2 (D'Arcangelo et al. 1999; Hiesberger et al. 1999). Notably, VLDLR and ApoER2 


\section{O. Marín et al.}

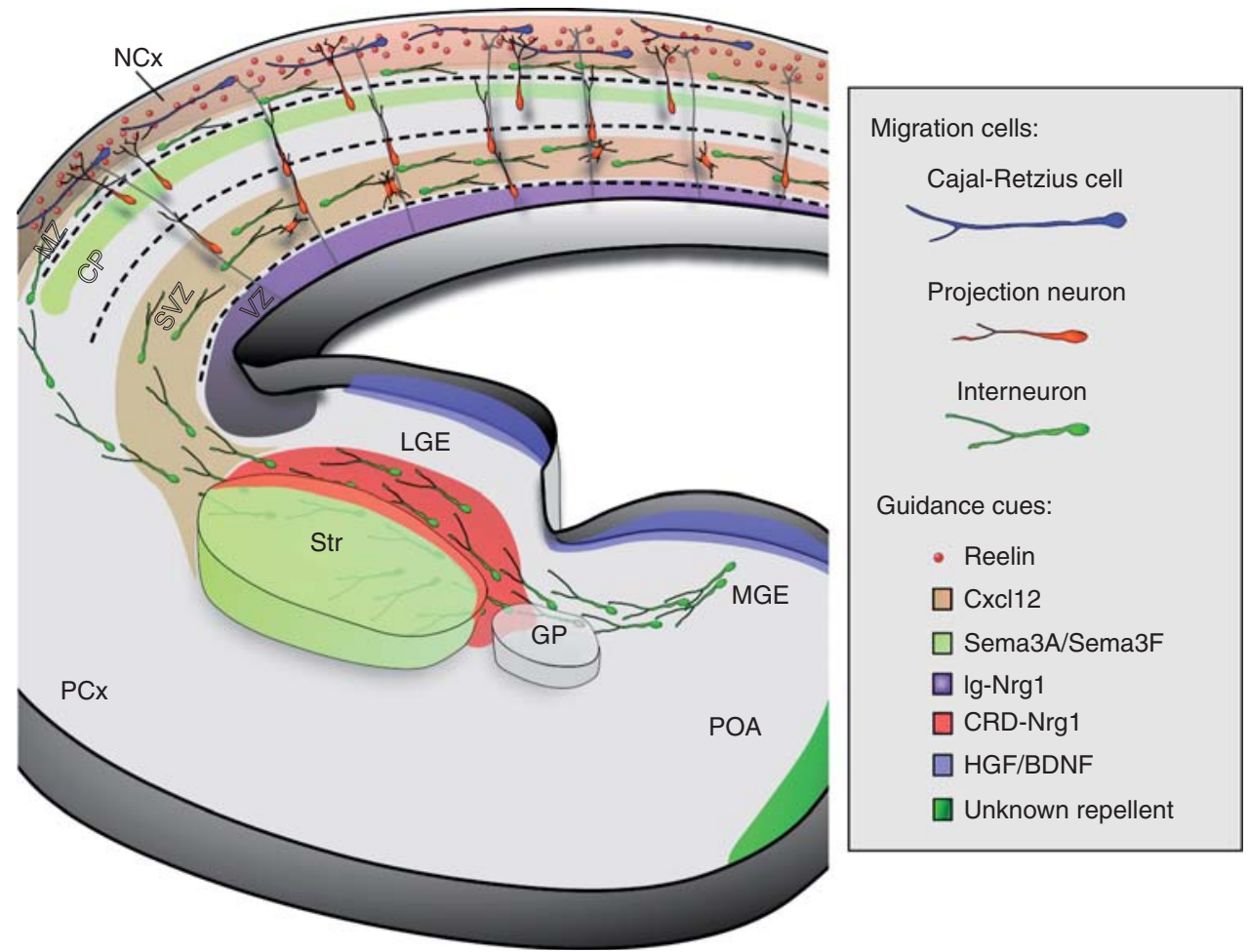

Figure 4. Guidance cues and neuronal migration in the telencephalon. The schema shows a coronal slice of the telencephalon at midembryonic stages, in which the main cortical migrations and their guidance cues are indicated. Interneurons born in the medial ganglionic eminence (MGE) migrate tangentially through the subpallium to reach the cortex. Some of these interneurons enter the striatum (striatal interneurons), whereas others continue toward the cortex (cortical interneurons), sorting out through a mechanism that involves Sema3A and Sema3F. Cortical interneurons advance toward the cortex following a corridor of lateral ganglionic eminence (LGE)-derived cells that express CRD-Nrg1 but not semaphorins. Interneurons are guided toward the cortex by a combination of motogenic (HGF/BDNF) and chemoattractive factors (Ig-Nrg1). Once in the cortex, chemokine signaling (Cxcl12) restricts the migration of interneurons through two streams, the marginal zone (MZ) and the subventricular zone (SVZ). Cajal-Retzius cells also use Cxcl12 to disperse through the MZ in opposite direction to interneurons. Cajal-Retzius cells produce Reelin, which along with other factors such as semaphorins, guide the migration of projection neurons. (CP) cortical plate; (GP) globus pallidum; (IZ) intermediate zone; (MZ) marginal zone; (NCx) neocortex; (PCx) piriform cortex; (Str) striatum; (SVZ/VZ) subventricular/ventricular zones.

double mutants phenocopy the defects found in reeler (Trommsdorff et al. 1999), although each receptor seems to play specific roles in this process (Hack et al. 2007).

The layering defects found in reeler and VLDLR/ApoER2 double mutant mice can also be found in two other spontaneous mutant mice, scrambler and yotari, which carry mutations in Dab1 (Gonzalez et al. 1997; Howell et al. 2000; Rice et al. 1998; Sheldon et al. 1997; Trommsdorff et al. 1999; Yoneshima et al. 1997). Biochemical studies suggest Reelin binding to its receptors induces tyrosine phosphorylation of Dab1 (Howell et al. 1999; Howell et al. 2000), which triggers a signaling cascade that instructs neurons to adopt their proper destination in the cortex. Notably, mice harboring point mutations in all tyrosine residues of Dab1 also phenocopy reeler mice (Howell et al. 2000), suggesting that the tyrosine phosphorylation of Dab1 is a key step in Reelin signaling. Tyrosine phosphorylation of Dab1 is markedly reduced on simultaneous disruption of Src and Fyn, the two kinases 
that are responsible for this phosphorylation (Arnaud et al. 2003; Bock and Herz 2003). Src/Fyn double mutant mice display similar cortical and cerebellar lamination defects than Dabl and Reelin mutants (Kuo et al. 2005).

Dab1 phosphorylation is finally translated into the regulation of microtubule dynamics, as supported by several lines of evidence. First, tyrosine phosphorylation of Dab1 is coupled to the activation of PI3K in the leading processes of migrating neurons. This in turn activates AKT and induces the serine phosphorylation of GSK3 $\beta$, which inhibits its activity (Beffert et al. $2004)$. One of the major substrates of GSK3 $\beta$ is the microtubule associated protein tau, which stabilizes microtubules in its unphosphorylated state. Under physiological conditions, activation of Dab1 might function to maintain tau phosphorylation, thereby promoting microtubule stability. Accordingly, both reeler and VLDLR/ ApoER2 double mutant mice show hyperphosphorylation of tau at Ser202 and Thr205, two GSK3 $\beta$ sites (Hiesberger et al. 1999). Moreover, Reelin signaling induces the phosphorylation of GSK3 $\beta$ at its tyrosine residue, leading to its activation. Activated GSK3 $\beta$ functions synergistically with CDK5 to phosphorylate another microtubule associated protein, MAP1B (Gonzalez-Billault et al. 2005). Phosphorylation of MAP1B is believed to regulate microtubule stability and the cross talk between microtubules and actin filaments in axonal growth cones (Kawauchi et al. 2005). These opposite effects on MAP1B and tau phosphorylation likely reflect a very dynamic regulation of microtubule dynamics by Reelin signaling, depending on the context of cellular compartment or phases of migration. Third, Dab1 interacts with Lis1, a protein implicated in the human brain developmental disorder lissencephaly. This interaction depends on the tyrosine phosphorylation of Dab1 (Assadi et al. 2003). Furthermore, Lis1 mutations associated with severe phenotypes in humans disrupt the Lis1-Dab1 interaction. In addition, the compound Reelin/Lis1 heterozygous mice show a greater degree of cortical malformation than the individual heterozygotes, suggesting an epistatic relationship of the two genes (Assadi et al. 2003). Taken together, these studies suggest that the Reelin signaling pathway regulates microtubule dynamics through multiple signaling components.

\section{MECHANISMS AND CUES GUIDING TANGENTIAL NEURONAL MIGRATIONS}

\section{Cellular Interactions During Tangential Migration}

Tangentially migrating neurons do not seem to follow radial glial fibers but instead interact with other cell types (Corbin et al. 2001; Marín and Rubenstein 2001). In general, tangentially migrating cells can move in clusters, as it is the case of olfactory bulb interneurons, or individually, as it happens for instance with cortical interneurons or Cajal-Retzius cells. Cellular interactions also differ depending on the nature of the substrate. They can be homotypic, when interactions occur between cells of the same class, or heterotypic, when migrating cells rely on the contact with other cell types for their migration.

Different types of homotypic interactions support tangential migration. Homotypic interactions are highly permissive when neurons move through territories that are hostile to migration. This is the case, for example, of neuroblasts migrating from the lateral ventricles of the telencephalon toward the olfactory bulb in the adult brain (Wichterle et al. 1997). In this type of collective movement, known as chain migration, neuroblasts crawl on each other as they move forward, using adjacent migrating cells as their main substrate. This mode of migration allows neurons to form an isolated microenvironment in which each individual cell promotes the migration of others.

Neurons may also develop inhibitory homotypic interactions. This mode of migration, known as contact inhibition, was first described to define the behavior of fibroblasts confronting each other in vitro, where they retract their protrusions and change direction on contact (Abercrombie and Heaysman 1953). This strategy allows neurons to achieve directional migration in the absence of chemotactic gradients, because it favors the movement of cells toward areas with less cell density. Recent in vitro experiments 
suggests that Cajal-Retzius cells derived from the cortical hem may use this mechanism to disperse throughout the surface of the cerebral cortex during early corticogenesis (Borrell and Marín 2006), although the molecular mechanisms underlying this process are currently unknown. It should be noted, however, that members of the planar cell polarity (PCP) pathway have been shown to mediate contact inhibition of locomotion in neural crest cells (Carmona-Fontaine et al. 2008), and PCP proteins are likely involved in the migration of telencephalic neurons (Ying et al. 2009).

Most tangentially migrating neurons rely on heterotypic interactions with their substrates. In the most common scenario, neurons respond to cues present in the extracellular matrix or in the surface of other cells to achieve directional migration. An extreme case of heterotypic migration is used by neurons that move along axons to reach their final destination. This form of migration resembles axon fasciculation, and is used, for example, by the neurons responsible for producing the Gonadotropin-releasing hormone $(\mathrm{GnRH}$, also known as Luteinizing hormone-releasing hormone, LHRH). During development, these neurons traverse the forebrain from the olfactory bulb to the hypothalamus following vomeronasal axons (Wray 2002).

\section{Chemotaxis in Tangential Migration}

Tangentially migrating neurons most frequently achieve directional migration by interpreting chemotactic gradients. Almost every molecule known to influence axon guidance has also been implicated in tangential migration. The list not only includes members of the classical families of guidance factors, such as Slits, netrins, and semaphorins, but also growth factors or morphogenetic proteins. This circumstance strongly suggests that the molecular mechanisms responsible for the chemotactic response share many similarities between axons and migrating neurons, even though the cellular strategies adopted by both might be different.

Many signals responsible for the guidance of cortical interneurons have been identified over the past few years (Fig. 4), in particular for those derived from the medial ganglionic eminence
(MGE). MGE-derived interneurons achieve directional migration by integrating chemoattractive and chemorepellent cues (Marín et al. 2003; Wichterle et al. 2003) (Fig. 4). In addition, several growth factors, including BDNF, NT4, and HGF increases the migratory rate of MGEderived interneurons in vitro and are thought to promote the movement of these cells in vivo (Polleux et al. 2002; Pozas and Ibañez 2005). The mechanisms through which these signals elicit a potent migratory response in MGEderived cells are not completely understood, but are thought to involve activation of PI3K/ AKT and ERK pathways (Polleux et al. 2002; Segarra et al. 2005).

The best-characterized chemoattractant for MGE-derived cells is Neuregulin-1 (Nrg1), which acts primarily through ErbB4 (Yau et al. 2003), a member of the EGF receptor family (Buonanno and Fischbach 2001). Two different isoforms of Nrg1 are expressed in the developing telencephalon (Flames et al. 2004). Type III Nrg1 (CRD-Nrg1) is expressed in the migratory route used by interneurons to cross the lateral ganglionic eminence (LGE) toward the cortex. This form of Nrg1 is membrane-bound, and so it is thought to function as a permissive substrate for interneuron migration. In contrast, type I/II Nrg1 (Ig-Nrg1) expression is restricted to the developing pallium. Because this later molecule is cleaved from the membrane, it is likely that a gradient of Ig-Nrg1 contributes to drive MGE-derived interneurons toward the cortex. The analysis of Nrg1 and ErbB4 mutants are consistent with this hypothesis, as both show delayed migration from the MGE and deficits in cortical interneurons (Flames et al. 2004; Neddens and Buonanno 2009). Recent studies have begun to explore the cellular mechanisms through which Nrg1 directs the guidance of cortical interneurons (Martini et al. 2009). In vitro experiments suggest that migrating interneurons respond to a gradient of Nrg1 by generating new leading process branches that are better aligned with the source of the gradient and, subsequently, selecting those branches to continue their migration. Thus, in contrast to its role in axon guidance (López-Bendito et al. 2006), Nrg1 
does not influence neuronal migration by reorienting previously existing growth cones. The molecular basis for this disparity is currently unknown, but is likely to involve fundamental differences in the way growing axons and migrating neurons integrate chemotactic signals.

The progression of MGE-derived cells toward the cortex is also guided by chemorepellents, which preclude their entry into undesired targets (Fig. 4). For instance, interneurons are prevented from migrating in ventral direction by a so far unidentified chemorepellent activity present in the preoptic area (Marín et al. 2003; Wichterle et al. 2003). MGE-derived cortical interneurons also avoid the developing striatum in response to class III semaphorins (Sema3A and Sema3F) expressed in this structure (Marín et al. 2001; Nóbrega-Pereira et al. 2008). This mechanism involves Nrp1 and Nrp2, the receptors for Sema3A and Sema3F, respectively. In addition, recent work has suggested that Robo receptors might be involved in regulating the migration of cortical interneurons around the striatum in a mechanism that is likely independent of Slits (Andrews et al. 2007; Marín et al. 2003).

The mechanisms controlling the guidance of interneurons within the developing cortex are less understood. Cortical interneurons disperse tangentially through the cortex following two main routes of migration, the $\mathrm{MZ}$ and the SVZ (Lavdas et al. 1999), initially avoiding the CP (López-Bendito et al. 2008). Chemokines are responsible for maintaining migrating interneurons within the MZ and SVZ as they disperse tangentially throughout the cortex ( $\mathrm{Li}$ et al. 2008; López-Bendito et al. 2008; Tiveron et al. 2006). Cells in these layers express Cxcl12, a potent chemoattractant for MGEderived cells. Interneurons in turn express Cxcr4, a receptor for this chemokine. Loss of Cxcr4 function does not prevent interneurons from reaching the cortex in normal numbers, but it disrupts their distribution as they migrate within the cortex (Tiveron et al. 2006). This phenotype causes premature interneuron entry into the $\mathrm{CP}$, which disrupts their normal laminar and regional distribution ( $\mathrm{Li}$ et al. 2008; López-Bendito et al. 2008). The mechanisms controlling the laminar distribution of interneurons have not been yet identified, but current evidence suggests that this process is independent of Dab1 signaling (Pla et al. 2006).

\section{COORDINATION OF NEURONAL MIGRATION AND AXON GUIDANCE}

Neuronal migration and axon guidance are frequently studied as independent processes, but the normal development of neural circuits requires their coordination. Over the past few years, we have learned a great deal about the integration of both mechanisms in some aspects of neural development, in particular in relation to the role of intermediate targets in axon guidance.

\section{Migration of Guidepost Cells for Axon Guidance}

Guidepost cells represent a clear example that illustrates how neuronal migration and axon guidance are coordinated during the wiring of brain circuitry. Guidepost cells are typically positioned at critical decision points within the migratory pathway of axons and provide them with guidance information (see Dickson and Zou 2010).

The guidance of three major forebrain projections relies on guidepost cells: the corpus callosum, the thalamocortical projection, and the lateral olfactory tract (Fig. 5). Cortical commissural axons rely on cues provided by a population of cells named the "glial sling" to successfully navigate the midline. Neurons that form the glial sling derive from the SVZ and migrate toward the midline around E17.5, just before the arrival of the first commissural axons (Shu et al. 2003b). In mouse mutants for one of the Nuclear factor I genes, Nfia, sling cells fail to reach the midline and instead migrate toward the septum. As a consequence, the corpus callosum does not form in Nfia mutant mice (Shu et al. 2003a). The molecular nature of the cues guiding sling cells remains unknown, as is the case for corridor cells, the population of GABAergic neurons that serve as an intermediate target for thalamocortical axons. These neurons derive from the LGE 
O. Marín et al.

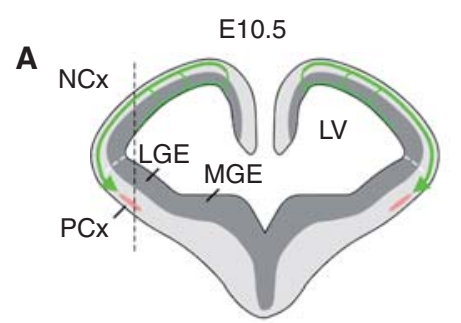

$A^{\prime}$

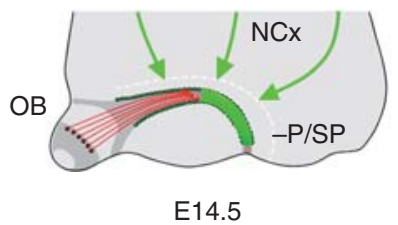

B

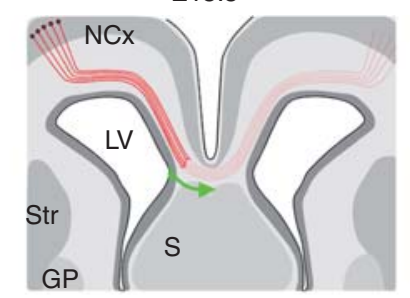

B'

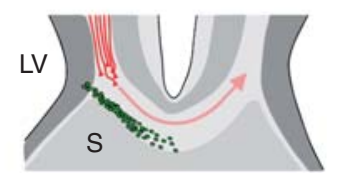

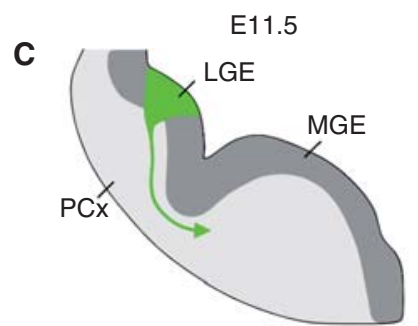

C'

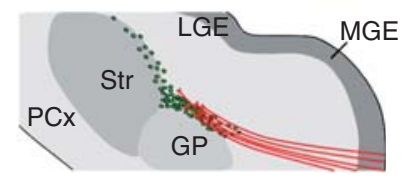

E13.5

Figure 5. Migrating guidepost cells in the developing forebrain. ( $\left.A, A^{\prime}\right)$ LOT cells are generated early in development at the ventricular zone of the neocortex. They migrate tangentially to the piriform cortex, where they arrive at 3-4 $\mathrm{d}$ in advance to the olfactory axonal tract. $\left(B, B^{\prime}\right)$ Glial sling cells derive from the ventricular zone in the medial neocortex at E15.5. They migrate toward the midline to contribute to the formation of the corpus callosum through signaling that involves Slit2. $\left(C, C^{\prime}\right)$ A subpopulation of LGE-derived interneurons migrates ventrally, forming a cellular corridor that expresses CRD-NRG1. These guidepost cells are required for the migration of thalamocortical axons as they extend through the basal telencephalon on their way to the cortex. (GP) globus pallidum; (LGE) lateral ganglionic eminence; (LV) lateral ventricle; (MGE) medial ganglionic eminence; (NCx) neocortex; (OB) olfactory bulb; (PCx) piriform cortex; (P/SP) pallium-subpallium boundary; (S) septum; (Str) striatum.

and migrate tangentially in ventral direction until the region where thalamocortical axons (TCAs) enter the telencephalon (López-Bendito et al. 2006). Through a mechanism that involves CRD-Nrg1/ErbB4 signaling, corridor cells facilitate the migration of TCAs through the most ventral aspect of the subpallium, a territory hostile for the growth of thalamic axons.

The migration of lateral olfactory tract (LOT) cells is probably the best characterized of all three. This population of neurons is generated very early during telencephalic development (E10.5) by progenitor cells in the pallium (Tomioka et al. 2000). LOT cells subsequently migrate laterally through the MZ until they reach the pallial-subpallial boundary, where they turn $90^{\circ}$ and disperse in rostrocaudal direction around the piriform cortex. This migration requires the coordinated activity of Sema3F, which restrict the migration of LOT cells close to the pial surface (Ito et al. 2008); ephrinA5, which prevents the migration of LOT cells into the subpallium (Nomura et al. 2006); and Netrin-1, which guides LOT cells surrounding the piriform cortex (Kawasaki et al. 2006). The final location of LOT cells accompanies the route of the prospective lateral olfactory tract, whose axons will navigate through the space created by LOT cells deep to the piriform cortex.

\section{Integration of Migration and Axon Guidance Programs Within Individual Cells}

The coordination of migratory and axon guidance programs does not only occur at the population level, as described previously, but it also poses a very interesting challenge for individual cells. It is generally assumed that neuronal migration is largely incompatible with other programs of differentiation because this later process drives cells into the acquisition of morphological features that are unsuited for migration. Specifically, neuronal differentiation involves the growth of dendrites and axons in specific patterns, which may restrict their movement and break the polarity that cells require to migrate. To prevent this from happening, migrating neurons express genes that repress the 
differentiation program of the cell. In migrating cortical interneurons, for instance, $D l x 1$ and Dlx2 repress the expression of other genes involved in axonal growth, synaptogenesis, and axon and dendritic branching (Cobos et al. 2007). One of these genes is PAK3, an intracellular kinase that is normally activated at the end of the migration of cortical interneurons and that is involved in driving the growth of dendrites and axons in these cells.

It is well known, however, that certain types of neurons are able to migrate as they simultaneously extend an axon in the opposite direction. This is the case of pyramidal cells, which grow their axon as soon as they start migrating toward the CP (Noctor et al. 2004; Schwartz et al. 1991). How do cells manage to run these programs in parallel? One possibility is that neuronal migration and axon growth do not occur simultaneously, but instead in alternative cycles. In favor of this hypothesis is the observation that pyramidal cells extend their axons when they pause their migration in the subventricular zone (Fig. 2). Thus, the formation of the axon is preceded by a phase in which the cell loses its initial polarization and becomes multipolar, until one of its multiple processes is selected as the axon and oriented toward the VZ (Kriegstein and Noctor 2004). This suggests that cell migration and axon growth might not occur exactly at the same time, at least during this early phase. Additional time-lapse studies with high temporal resolution would be required to solve this question.

\section{CONCLUDING REMARKS}

There has been much progress in understanding the mechanisms regulating neuronal migration over the past few years. In particular, many guidance cues have been identified for different classes of migratory neurons and our knowledge of the mechanisms underlying the cell biology of migration has rapidly expanded, in particular in relation to nucleokinesis. There are, however, major questions, old and new, that remain unanswered. For example, we know virtually nothing about the mechanisms that coordinate the guidance of the leading process with the movement of the nucleus. Similarly, we ignore how guidance cues are integrated by migrating neurons with branched leading process, or how the guidance process is dissociated in migrating neurons that extend axons as they move. These and other questions promise an exciting future for research in this field.

\section{ACKNOWLEDGMENTS}

Work in our laboratories is supported by grants from the Spanish Government (SAF200800770, CONSOLIDER CSD2007-00023) and the EURYI scheme award (see www.esf.org/euryi) to O.M., and from NIH RO1 Grant NS051874 to L-H.T. M.V. was supported by a fellowship from the Generalitat Valenciana (CTBPRA/ 2005/021). L.-H.T. is an investigator of the Howard Hughes Medical Institute.

\section{REFERENCES}

Abercrombie M, Heaysman J. 1953. Observations on the social behaviour of cells in tissue culture. I. Speed of movement of chick heart fibroblasts in relation to their mutual contacts. Exp Cell Res 5: 111-131.

Adams NC, Tomoda T, Cooper M, Dietz G, Hatten ME. 2002. Mice that lack astrotactin have slowed neuronal migration. Development 129: 965-972.

Andrews WD, Barber M, Parnavelas JG. 2007. Slit-Robo interactions during cortical development. J Anat 211: $188-198$.

Ang ES Jr, Haydar TF, Gluncic V, Rakic P. 2003. Four-dimensional migratory coordinates of GABAergic interneurons in the developing mouse cortex. J Neurosci 23: 5805-5815.

Angevine JB, Sidman RL. 1961. Autoradiographic study of cell migration during histogenesis of cerebral cortex in the mouse. Nature 192: 766-768.

Anton ES, Kreidberg JA, Rakic P. 1999. Distinct functions of $\alpha 3$ and $\alpha(v)$ integrin receptors in neuronal migration and laminar organization of the cerebral cortex. Neuron 22: 277-289.

Anton ES, Marchionni MA, Lee KF, Rakic P. 1997. Role of GGF/neuregulin signaling in interactions between migrating neurons and radial glia in the developing cerebral cortex. Development 124: 3501-3510.

Arnaud L, Ballif BA, Forster E, Cooper JA. 2003. Fyn tyrosine kinase is a critical regulator of disabled-1 during brain development. Curr Biol 13: 9-17.

Assadi AH, Zhang G, Beffert U, McNeil RS, Renfro AL, Niu S, Quattrocchi CC, Antalffy BA, Sheldon M, Armstrong DD, et al. 2003. Interaction of reelin signaling and Lis1 in brain development. Nat Genet 35: 270-276. 
O. Marín et al.

Aumais JP, Tunstead JR, McNeil RS, Schaar BT, McConnell SK, Lin SH, Clark GD, Yu-Lee LY. 2001. NudC associates with Lis1 and the dynein motor at the leading pole of neurons. J Neurosci 21: RC187.

Ayala R, Shu T, Tsai LH. 2007. Trekking across the brain: The journey of neuronal migration. Cell 128: 29-43.

Bader BL, Rayburn H, Crowley D, Hynes RO. 1998 Extensive vasculogenesis, angiogenesis, organogenesis precede lethality in mice lacking all $\alpha \mathrm{v}$ integrins. Cell 95: 507-519.

Bai J, Ramos RL, Ackman JB, Thomas AM, Lee RV, LoTurco JJ. 2003. RNAi reveals doublecortin is required for radial migration in rat neocortex. Nat Neurosci 6: 1277-1283.

Beffert U, Weeber EJ, Morfini G, Ko J, Brady ST, Tsai LH, Sweatt JD, Herz J. 2004. Reelin and cyclin-dependent kinase 5-dependent signals cooperate in regulating neuronal migration and synaptic transmission. J Neurosci 24: 1897-1906.

Bellion A, Baudoin JP, Alvarez C, Bornens M, Metin C 2005. Nucleokinesis in tangentially migrating neurons comprises two alternating phases: Forward migration of the Golgi/centrosome associated with centrosome splitting and myosin contraction at the rear. J Neurosci 25: 5691-5699.

Bielle F, Griveau A, Narboux-Neme N, Vigneau S, Sigrist M, Arber S, Wassef M, Pierani A. 2005. Multiple origins of Cajal-Retzius cells at the borders of the developing pallium. Nat Neurosci 8: 1002-1012.

Bock HH, Herz J. 2003. Reelin activates SRC family tyrosine kinases in neurons. Curr Biol 13: 18-26.

Borrell V, Marín O. 2006. Meninges control tangential migration of hem-derived Cajal-Retzius cells via CXCL12/CXCR4 signaling. Nat Neurosci 9: 1284-1293.

Britto JM, Johnston LA, Tan SS. 2009. The stochastic search dynamics of interneuron migration. Biophys $J$ 97: 699-709.

Buonanno A, Fischbach GD. 2001. Neuregulin and ErbB receptor signaling pathways in the nervous system. Curr Opin Neurobiol 11: 287-296.

Burgess HA, Martinez S, Reiner O. 1999. KIAA0369, doublecortin-like kinase, is expressed during brain development. J Neurosci Res 58: 567-575.

Calderwood DA, Huttenlocher A, Kiosses WB, Rose DM, Woodside DG, Schwartz MA, Ginsberg MH. 2001. Increased filamin binding to $\beta$-integrin cytoplasmic domains inhibits cell migration. Nat Cell Biol 3: $1060-1068$.

Campbell K, Gotz M. 2002. Radial glia: Multi-purpose cells for vertebrate brain development. Trends Neurosci 25: 235-238.

Carmona-Fontaine C, Matthews HK, Kuriyama S, Moreno M, Dunn GA, Parsons M, Stern CD, Mayor R. 2008. Contact inhibition of locomotion in vivo controls neural crest directional migration. Nature 456: 957-961.

Caviness VS Jr, 1982. Neocortical histogenesis in normal and reeler mice: A developmental study based upon [3H]thymidine autoradiography. Brain Res 256: 293-302.

Chae T, Kwon YT, Bronson R, Dikkes P, Li E, Tsai LH. 1997. Mice lacking p35, a neuronal specific activator of Cdk5, display cortical lamination defects, seizures, and adult lethality. Neuron 18: 29-42.

Cina C, Maass K, Theis M, Willecke K, Bechberger JF, Naus CC. 2009. Involvement of the cytoplasmic C-terminal domain of connexin 43 in neuronal migration. J Neurosci 29: 2009-2021.

Cobos I, Borello U, Rubenstein JL. 2007. Dlx transcription factors promote migration through repression of axon and dendrite growth. Neuron 54: 873-888.

Corbin JG, Nery S, Fishell G. 2001. Telencephalic cells take a tangent: Non-radial migration in the mammalian forebrain. Nat Neurosci 4: 1177-1182.

D’Arcangelo G, Homayouni R, Keshvara L, Rice DS, Sheldon M, Curran T. 1999. Reelin is a ligand for lipoprotein receptors. Neuron 24: 471-479.

D’Arcangelo G, Miao GG, Chen SC, Soares HD, Morgan JI, Curran T. 1995. A protein related to extracellular matrix proteins deleted in the mouse mutant reeler. Nature 374: 719-723.

Dawe AL, Caldwell KA, Harris PM, Morris NR, Caldwell GA. 2001. Evolutionarily conserved nuclear migration genes required for early embryonic development in Caenorhabditis elegans. Dev Genes Evol 211: 434-441.

des Portes V, Francis F, Pinard JM, Desguerre I, Moutard ML, Snoeck I, Meiners LC, Capron F, Cusmai R, Ricci $\mathrm{S}$, et al. 1998. doublecortin is the major gene causing X-linked subcortical laminar heterotopia (SCLH). Hum Mol Genet 7: 1063-1070.

Deuel TA, Liu JS, Corbo JC, Yoo SY, Rorke-Adams LB, Walsh CA. 2006. Genetic interactions between doublecortin and doublecortin-like kinase in neuronal migration and axon outgrowth. Neuron 49: 41-53.

Dhavan R, Tsai LH. 2001. A decade of CDK5. Nat Rev Mol Cell Biol 2: 749-759.

Dickson B, Zou Y. 2010. Navigating intermediate targets: the nervous system midline. Cold Spring Harb Perspect Biol 2: a002055.

Dulabon L, Olson EC, Taglienti MG, Eisenhuth S, McGrath B, Walsh CA, Kreidberg JA, Anton ES. 2000. Reelin binds $\alpha 3 \beta 1$ integrin and inhibits neuronal migration. Neuron 27: $33-44$.

Edmondson JC, Liem RK, Kuster JE, Hatten ME. 1988. Astrotactin: A novel neuronal cell surface antigen that mediates neuron-astroglial interactions in cerebellar microcultures. J Cell Biol 106: 505-517.

Elias LA, Wang DD, Kriegstein AR. 2007. Gap junction adhesion is necessary for radial migration in the neocortex. Nature 448: 901-907.

Feng Y, Chen MH, Moskowitz IP, Mendonza AM, Vidali L, Nakamura F, Kwiatkowski DJ, Walsh CA. 2006. Filamin A (FLNA) is required for cell-cell contact in vascular development and cardiac morphogenesis. Proc Natl Acad Sci 103: 19836-19841.

Fishell G, Hatten ME. 1991. Astrotactin provides a receptor system for CNS neuronal migration. Development 113: $755-765$.

Flames N, Long JE, Garratt AN, Fischer TM, Gassmann M, Birchmeier C, Lai C, Rubenstein JL, Marín O. 2004. Short- and long-range attraction of cortical GABAergic interneurons by neuregulin-1. Neuron 44: 251-261. 
Francis F, Koulakoff A, Boucher D, Chafey P, Schaar B, Vinet MC, Friocourt G, McDonnell N, Reiner O, Kahn A, et al. 1999. Doublecortin is a developmentally regulated, microtubule-associated protein expressed in migrating and differentiating neurons. Neuron 23: 247-256.

Francis F, Meyer G, Fallet-Bianco C, Moreno S, Kappeler C, Socorro AC, Tuy FP, Beldjord C, Chelly J. 2006. Human disorders of cortical development: From past to present. Eur J Neurosci 23: 877-893.

Friocourt G, Liu JS, Antypa M, Rakic S, Walsh CA, Parnavelas JG. 2007. Both doublecortin and doublecortin-like kinase play a role in cortical interneuron migration. J Neurosci 27: 3875-3883.

Gambello MJ, Darling DL, Yingling J, Tanaka T, Gleeson JG, Wynshaw-Boris A. 2003. Multiple dose-dependent effects of Lis1 on cerebral cortical development. J Neurosci 23: 1719-1729.

Georges-Labouesse E, Mark M, Messaddeq N, Gansmüller A. 1998. Essential role of $\alpha 6$ integrins in cortical and retinal lamination. Curr Biol 8: 983-986.

Gilmore EC, Ohshima T, Goffinet AM, Kulkarni AB, Herrup K. 1998. Cyclin-dependent kinase 5-deficient mice demonstrate novel developmental arrest in cerebral cortex. J Neurosci 18: 6370-6377.

Gleeson JG, Allen KM, Fox JW, Lamperti ED, Berkovic S, Scheffer I, Cooper EC, Dobyns WB, Minnerath SR, Ross ME, Walsh CA. 1998. Doublecortin, a brain-specific gene mutated in human X-linked lissencephaly and double cortex syndrome, encodes a putative signaling protein. Cell 92: 63-72.

Gleeson JG, Lin PT, Flanagan LA, Walsh CA. 1999. Doublecortin is a microtubule-associated protein and is expressed widely by migrating neurons. Neuron $\mathbf{2 3}$ $257-271$.

Gonzalez-Billault C, Del Rio JA, Urena JM, JimenezMateos EM, Barallobre MJ, Pascual M, Pujadas L, Simo S, Torre AL, Gavin R, et al. 2005. A role of MAP1B in Reelin-dependent neuronal migration. Cereb Cortex 15: $1134-1145$.

Gonzalez JL, Russo CJ, Goldowitz D, Sweet HO, Davisson MT, Walsh CA. 1997. Birthdate and cell marker analysis of scrambler: A novel mutation affecting cortical development with a reeler-like phenotype. J Neurosci 17: 9204-9211.

Graus-Porta D, Blaess S, Senften M, Littlewood-Evans A, Damsky C, Huang Z, Orban P, Klein R, Schittny JC, Muller U. 2001. $\beta 1$-class integrins regulate the development of laminae and folia in the cerebral and cerebellar cortex. Neuron 31: 367-379.

Guo J, Yang Z, Song W, Chen Q, Wang F, Zhang Q, Zhu X. 2006. Nudel contributes to microtubule anchoring at the mother centriole and is involved in both dyneindependent and -independent centrosomal protein assembly. Mol Biol Cell 17: 680-689.

Gupta A, Tsai LH, Wynshaw-Boris A. 2002. Life is a journey: A genetic look at neocortical development. Nat Rev Genet 3: 342-355.

Gupta A, Sanada K, Miyamoto DT, Rovelstad S, Nadarajah B, Pearlman AL, Brunstrom J, Tsai LH. 2003. Layering defect in p35 deficiency is linked to improper neuronal-glial interaction in radial migration. Nat Neurosci 6: 1284-1291.
Hack I, Hellwig S, Junghans D, Brunne B, Bock HH, Zhao S, Frotscher M. 2007. Divergent roles of ApoER2 and Vldlr in the migration of cortical neurons. Development 134: 3883-3891.

Hatten ME. 1999. Central nervous system neuronal migration. Annu Rev Neurosci 22: 511-539.

Hattori M, Adachi H, Tsujimoto M, Arai H, Inoue K. 1994. Miller-Dieker lissencephaly gene encodes a subunit of brain platelet-activating factor acetylhydrolase. Nature 370: $216-218$.

Hiesberger T, Trommsdorff M, Howell BW, Goffinet A, Mumby MC, Cooper JA, Herz J. 1999. Direct binding of Reelin to VLDL receptor and ApoE receptor 2 induces tyrosine phosphorylation of disabled-1 and modulates tau phosphorylation. Neuron 24: 481-489.

Higginbotham HR, Gleeson JG. 2007. The centrosome in neuronal development. Trends Neurosci 30: 276-283.

Hirotsune S, Fleck MW, Gambello MJ, Bix GJ, Chen A, Clark GD, Ledbetter DH, McBain CJ, Wynshaw-Boris A. 1998. Graded reduction of Pafah1b1 (Lis1) activity results in neuronal migration defects and early embryonic lethality. Nat Genet 19: 333-339.

Hirotsune S, Takahara T, Sasaki N, Hirose K, Yoshiki A, Ohashi T, Kusakabe M, Murakami Y, Muramatsu M, Watanabe S, et al. 1995. The reeler gene encodes a protein with an EGF-like motif expressed by pioneer neurons. Nat Genet 10: 77-83.

Horesh D, Sapir T, Francis F, Wolf SG, Caspi M, Elbaum M Chelly J, Reiner O. 1999. Doublecortin, a stabilizer of microtubules. Hum Mol Genet 8: 1599-1610.

Howell BW, Herrick TM, Cooper JA. 1999. Reelin-induced tyrosine phosphorylation of disabled 1 during neuronal positioning. Genes Dev 13: 643-648.

Howell BW, Herrick TM, Hildebrand JD, Zhang Y, Cooper JA. 2000. Dab1 tyrosine phosphorylation sites relay positional signals during mouse brain development. Curr Biol 10: 877-885.

Ito K, Kawasaki T, Takashima S, Matsuda I, Aiba A, Hirata T. 2008. Semaphorin 3F confines ventral tangential migration of lateral olfactory tract neurons onto the telencephalon surface. J Neurosci 28: 4414-4422.

Jellinger K, Rett A. 1976. Agyria-pachygyria (lissencephaly syndrome). Neuropadiatrie 7: 66-91.

Kappeler C, Saillour Y, Baudoin JP, Tuy FP, Alvarez C, Houbron C, Gaspar P, Hamard G, Chelly J, Métin C, Francis F. 2006. Branching and nucleokinesis defects in migrating interneurons derived from doublecortin knockout mice. Hum Mol Genet 15: 1387-1400.

Kawasaki T, Ito K, Hirata T. 2006. Netrin 1 regulates ventral tangential migration of guidepost neurons in the lateral olfactory tract. Development 133: 845-853.

Kawauchi T, Chihama K, Nabeshima Y, Hoshino M. 2006a. Cdk5 phosphorylates and stabilizes p27kip1 contributing to actin organization and cortical neuronal migration. Nat Cell Biol 8: 17-26.

Kawauchi T, Chihama K, Nabeshima Y, Hoshino M. 2006b. Cdk5 phosphorylates and stabilizes p27kip1 contributing to actin organization and cortical neuronal migration. Nat Cell Biol 8: 17-26.

Kawauchi T, Chihama K, Nishimura YV, Nabeshima Y, Hoshino M. 2005. MAP1B phosphorylation is 


\section{O. Marín et al.}

differentially regulated by Cdk5/p35, Cdk5/p25, and JNK. Biochem Biophys Res Commun 331: 50-55.

Ko J, Humbert S, Bronson RT, Takahashi S, Kulkarni AB, Li E, Tsai LH. 2001. p35 and p39 are essential for cyclindependent kinase 5 function during neurodevelopment. J Neurosci 21: 6758-6771.

Koizumi H, Tanaka T, Gleeson JG. 2006. Doublecortin-like kinase functions with doublecortin to mediate fiber tract decussation and neuronal migration. Neuron 49: 55-66.

Kriegstein AR, Noctor SC. 2004. Patterns of neuronal migration in the embryonic cortex. Trends Neurosci 27: 392-399.

Kuo G, Arnaud L, Kronstad-O’Brien P, Cooper JA. 2005. Absence of Fyn and Src causes a reeler-like phenotype. J Neurosci 25: 8578-8586.

Kwon YT, Tsai LH. 1998. A novel disruption of cortical development in $\mathrm{p} 35(-/-)$ mice distinct from reeler. J Comp Neurol 395: 510-522.

Lambert de Rouvroit C, Goffinet AM. 2001. Neuronal migration. Mech Dev 105: 47-56.

Lavdas AA, Grigoriou M, Pachnis V, Parnavelas JG. 1999. The medial ganglionic eminence gives rise to a population of early neurons in the developing cerebral cortex. J Neurosci 19: 7881-7888.

Li J, Lee WL, Cooper JA. 2005. NudEL targets dynein to microtubule ends through LIS1. Nat Cell Biol 7: 686-690.

Li G, Adesnik H, Li J, Long J, Nicoll RA, Rubenstein JLR, Pleasure SJ. 2008. Regional distribution of cortical interneurons and development of inhibitory tone are regulated by Cxcl12/Cxcr4 signaling. J Neurosci 28: 1085-1098.

Li BS, Zhang L, Gu J, Amin ND, Pant HC. 2000. Integrin $\alpha$ (1) $\beta(1)$-mediated activation of cyclin-dependent kinase 5 activity is involved in neurite outgrowth and human neurofilament protein $\mathrm{H}$ Lys-Ser-Pro tail domain phosphorylation. J Neurosci 20: 6055-6062.

Lin AC, Holt CE. 2007. Local translation and directional steering in axons. EMBO J 26: 3729-3736.

Lin PT, Gleeson JG, Corbo JC, Flanagan L, Walsh CA. 2000. DCAMKL1 encodes a protein kinase with homology to doublecortin that regulates microtubule polymerization. J Neurosci 20: 9152-9161.

Loo DT, Kanner SB, Aruffo A. 1998. Filamin binds to the cytoplasmic domain of the $\beta 1$-integrin. Identification of amino acids responsible for this interaction. J Biol Chem 273: 23304-23312.

López-Bendito G, Cautinat A, Sánchez JA, Bielle F, Flames N, Garratt AN, Talmage DA, Role L, Charnay P, Marín O, Garel S. 2006. Tangential neuronal migration controls axon guidance: A role for Neuregulin-1 on thalamocortical axon navigation. Cell 125: 127-142.

López-Bendito G, Sánchez-Alcaniz JA, Pla R, Borrell V, Pico E, Valdeolmillos M, Marín O. 2008. Chemokine signaling controls intracortical migration and final distribution of GABAergic interneurons. J Neurosci 28: 1613-1624.

Marín O, López-Bendito G. 2006. Neuronal migration. In Evolution of nervous systems, Kaas J.H., ed. (Oxford: Academic Press), 169-186.

Marín O, Rubenstein JLR. 2001. A long, remarkable journey: Tangential migration in the telencephalon. Nat Rev Neurosci 2: 780-790.
Marín O, Valdeolmillos M, Moya F. 2006. Neurons in motion: Same principles for different shapes? Trends Neurosci 29: 655-661.

Marín O, Plump AS, Flames N, Sanchez-Camacho C, Tessier-Lavigne M, Rubenstein JL. 2003. Directional guidance of interneuron migration to the cerebral cortex relies on subcortical Slit1/2-independent repulsion and cortical attraction. Development 130: 1889-1901.

Marín O, Rubenstein JL. 2003. Cell migration in the forebrain. Annu Rev Neurosci 26: 441-483.

Marín O, Yaron A, Bagri A, Tessier-Lavigne M, Rubenstein JL. 2001. Sorting of striatal and cortical interneurons regulated by semaphorin/neuropilin interactions. Science 293: 872-875.

Martini FJ, Valiente M, López Bendito G, Szabó G, Moya F, Valdeolmillos M, Marín O. 2009. Biased selection of leading process branches mediates chemotaxis during tangential neuronal migration. Development 136: 41-50.

McCarty JH, Lacy-Hulbert A, Charest A, Bronson RT, Crowley D, Housman D, Savill J, Roes J, Hynes RO. 2005. Selective ablation of $\alpha \mathrm{v}$ integrins in the central nervous system leads to cerebral hemorrhage, seizures, axonal degeneration and premature death. Development 132: $165-176$.

McManus MF, Nasrallah IM, Pancoast MM, Wynshaw-Boris A, Golden JA. 2004. Lis1 is necessary for normal nonradial migration of inhibitory interneurons. Am J Pathol 165: 775-784.

Mesngon MT, Tarricone C, Hebbar S, Guillotte AM, Schmitt EW, Lanier L, Musacchio A, King SJ, Smith DS. 2006. Regulation of cytoplasmic dynein ATPase by Lis1. J Neurosci 26: 2132-2139.

Miyata T, Ogawa M. 2007. Twisting of neocortical progenitor cells underlies a spring-like mechanism for daughter-cell migration. Curr Biol 17: 146-151.

Miyata T, Kawaguchi A, Okano H, Ogawa M. 2001. Asymmetric inheritance of radial glial fibers by cortical neurons. Neuron 31: 727-741.

Morris SM, Albrecht U, Reiner O, Eichele G, Yu-Lee LY. 1998. The lissencephaly gene product Lis1, a protein involved in neuronal migration, interacts with a nuclear movement protein, NudC. Curr Biol 8: 603-606.

Nadarajah B, Parnavelas JG. 2002. Modes of neuronal migration in the developing cerebral cortex. Nat Rev Neurosci 3: 423-432.

Nasrallah IM, McManus MF, Pancoast MM, Wynshaw-Boris A, Golden JA. 2006. Analysis of non-radial interneuron migration dynamics and its disruption in Lis1+/mice. J Comp Neurol 496: 847-858.

Neddens J, Buonanno A. 2009. Selective populations of hippocampal interneurons express ErbB4 and their number and distribution is altered in ErbB4 knockout mice. Hippocampus doi: 10.1002/hipo.20675.

Nikolic M, Chou MM, Lu W, Mayer BJ, Tsai LH. 1998. The p35/Cdk5 kinase is a neuron-specific Rac effector that inhibits Pak1 activity. Nature 395: 194-198.

Nóbrega-Pereira S, Kessaris N, Du T, Kimura S, Anderson SA, Marín O. 2008. Postmitotic Nkx2-1 controls the migration of telencephalic interneurons by direct repression of guidance receptors. Neuron 59: 733-745. 
Noctor SC, Flint AC, Weissman TA, Dammerman RS, Kriegstein AR. 2001. Neurons derived from radial glial cells establish radial units in neocortex. Nature 409: 714-720.

Noctor SC, Martinez-Cerdeno V, Ivic L, Kriegstein AR. 2004. Cortical neurons arise in symmetric and asymmetric division zones and migrate through specific phases. Nat Neurosci 7: 136-144.

Nomura T, Holmberg J, Frisen J, Osumi N. 2006. Pax6dependent boundary defines alignment of migrating olfactory cortex neurons via the repulsive activity of ephrin A5. Development 133: 1335-1345.

Ogawa M, Miyata T, Nakajima K, Yagyu K, Seike M, Ikenaka K, Yamamoto H, Mikoshiba K. 1995. The reeler gene-associated antigen on Cajal-Retzius neurons is a crucial molecule for laminar organization of cortical neurons. Neuron 14: 899-912.

Ohshima T, Ward JM, Huh CG, Longenecker G, Veeranna, Pant HC, Brady RO, Martin LJ, Kulkarni AB. 1996. Targeted disruption of the cyclin-dependent kinase 5 gene results in abnormal corticogenesis, neuronal pathology and perinatal death. Proc Natl Acad Sci 93: 11173-11178.

Okada T, Keino-Masu K, Masu M. 2007. Migration and nucleogenesis of mouse precerebellar neurons visualized by in utero electroporation of a green fluorescent protein gene. Neurosci Res 57: 40-49.

Pla R, Borrell V, Flames N, Marín O. 2006. Layer acquisition by cortical GABAergic interneurons is independent of Reelin signaling. J Neurosci 26: 6924-6934.

Polleux F, Whitford KL, Dijkhuizen PA, Vitalis T, Ghosh A. 2002. Control of cortical interneuron migration by neurotrophins and PI3-kinase signaling. Development 129: $3147-3160$

Pozas E, Ibañez CF. 2005. GDNF and GFR $\alpha 1$ promote differentiation and tangential migration of cortical GABAergic neurons. Neuron 45: 701-713.

Rakic P. 1971. Guidance of neurons migrating to the fetal monkey neocortex. Brain Res 33: 471-476.

Rakic P. 1972. Mode of cell migration to the superficial layers of fetal monkey neocortex. J Comp Neurol 145: 61-83.

Rakic P. 1974. Neurons in rhesus monkey visual cortex: Systematic relation between time of origin and eventual disposition. Science 183: 425-427.

Rakic P. 1990. Principles of neural cell migration. Experientia 46: 882-891.

Rakic P. 2007. The radial edifice of cortical architecture: From neuronal silhouettes to genetic engineering. Brain Res Rev 55: 204-219.

Rakić S, Yanagawa Y, Obata K, Faux C, Parnavelas JG, Nikolić M. 2009. Cortical interneurons require $\mathrm{p} 35 / \mathrm{Cdk} 5$ for their migration and laminar organization. Cereb Cortex 19: $1857-1869$.

Reiner O, Carrozzo R, Shen Y, Wehnert M, Faustinella F, Dobyns WB, Caskey CT, Ledbetter DH. 1993. Isolation of a Miller-Dieker lissencephaly gene containing G protein $\beta$-subunit-like repeats. Nature 364: 717-721.

Rice DS, Curran T. 1999. Mutant mice with scrambled brains: Understanding the signaling pathways that control cell positioning in the CNS. Genes Dev 13: 2758-2773.
Rice DS, Sheldon M, D'Arcangelo G, Nakajima K, Goldowitz D, Curran T. 1998. Disabled-1 acts downstream of Reelin in a signaling pathway that controls laminar organization in the mammalian brain. Development 125: 3719-3729.

Rivas RJ, Hatten ME. 1995. Motility and cytoskeletal organization of migrating cerebellar granule neurons. J Neurosci 15: 981-989.

Sapir T, Elbaum M, Reiner O. 1997. Reduction of microtubule catastrophe events by LIS1, platelet-activating factor acetylhydrolase subunit. EMBO J 16: 6977-6984.

Sapir T, Shmueli A, Levy T, Timm T, Elbaum M, Mandelkow EM, Reiner O. 2008. Antagonistic effects of doublecortin and MARK2/Par-1 in the developing cerebral cortex. J Neurosci 28: 13008-13013.

Sarkisian MR, Bartley CM, Rakic P. 2008. Trouble making the first move: Interpreting arrested neuronal migration in the cerebral cortex. Trends Neurosci 31: 54-61.

Sasaki S, Shionoya A, Ishida M, Gambello MJ, Yingling J, Wynshaw-Boris A, Hirotsune S. 2000. A LIS1/NUDEL/ cytoplasmic dynein heavy chain complex in the developing and adult nervous system. Neuron 28: 681-696.

Schaar BT, McConnell SK. 2005. Cytoskeletal coordination during neuronal migration. Proc Natl Acad Sci 102: 13652-13657.

Schmid RS, Jo R, Shelton S, Kreidberg JA, Anton ES. 2005. Reelin, integrin and DAB1 interactions during embryonic cerebral cortical development. Cereb Cortex 15: $1632-1636$.

Schmid RS, Shelton S, Stanco A, Yokota Y, Kreidberg JA, Anton ES. 2004. $\alpha 3 \beta 1$ integrin modulates neuronal migration and placement during early stages of cerebral cortical development. Development 131: 6023-6031.

Schwartz ML, Rakic P, Goldman-Rakic PS. 1991. Early phenotype expression of cortical neurons: Evidence that a subclass of migrating neurons have callosal axons. Proc Natl Acad Sci 88: 1354-1358.

Segarra J, Balenci L, Drenth T, Maina F, Lamballe F. 2005. Combined signaling through ERKs, PI3K/AKT and $\mathrm{RACl} / \mathrm{p} 38$ is required for met-triggered cortical neuron migration. J Biol Chem 281: 4771-4778.

Sheldon M, Rice DS, D'Arcangelo G, Yoneshima H, Nakajima K, Mikoshiba K, Howell BW, Cooper JA, Goldowitz D, Curran T. 1997. Scrambler and yotari disrupt the disabled gene and produce a reeler-like phenotype in mice. Nature 389: 730-733.

Sheppard AM, Pearlman AL. 1997. Abnormal reorganization of preplate neurons and their associated extracellular matrix: An early manifestation of altered neocortical development in the reeler mutant mouse. J Comp Neurol 378: $173-179$.

Shu T, Li Y, Keller A, Richards LJ. 2003b. The glial sling is a migratory population of developing neurons. Development 130: 2929-2937.

Shu T, Ayala R, Nguyen MD, Xie Z, Gleeson JG, Tsai LH. 2004. Ndell operates in a common pathway with LIS1 and cytoplasmic dynein to regulate cortical neuronal positioning. Neuron 44: 263-277.

Shu T, Butz KG, Plachez C, Gronostajski RM, Richards LJ. 2003a. Abnormal development of forebrain midline glia 


\section{O. Marín et al.}

and commissural projections in Nfia knock-out mice. J Neurosci 23: 203-212.

Smith DS, Niethammer M, Ayala R, Zhou Y, Gambello MJ Wynshaw-Boris A, Tsai LH. 2000. Regulation of cytoplasmic dynein behaviour and microtubule organization by mammalian Lis1. Nat Cell Biol 2: 767-775.

Solecki DJ, Model L, Gaetz J, Kapoor TM, Hatten ME. 2004. Par6 $\alpha$ signaling controls glial-guided neuronal migration. Nat Neurosci 7: 1195-1203.

Stitt TN, Hatten ME. 1990. Antibodies that recognize astrotactin block granule neuron binding to astroglia. Neuron 5: 639-649.

Tabata H, Nakajima K. 2003. Multipolar migration: The third mode of radial neuronal migration in the developing cerebral cortex. J Neurosci 23: 9996-10001.

Takiguchi-Hayashi K, Sekiguchi M, Ashigaki S, Takamatsu M, Hasegawa H, Suzuki-Migishima R, Yokoyama M, Nakanishi S, Tanabe Y. 2004. Generation of reelinpositive marginal zone cells from the caudomedial wall of telencephalic vesicles. J Neurosci 24: 2286-2295.

Tanaka T, Koizumi H, Gleeson JG. 2006. The doublecortin and doublecortin-like kinase 1 genes cooperate in murine hippocampal development. Cereb Cortex 16: 69-73.

Tanaka D, Nakaya Y, Yanagawa Y, Obata K, Murakami F 2003. Multimodal tangential migration of neocortical GABAergic neurons independent of GPI-anchored proteins. Development 130: 5803-5813.

Tanaka T, Serneo FF, Higgins C, Gambello MJ, WynshawBoris A, Gleeson JG. 2004. Lis1 and doublecortin function with dynein to mediate coupling of the nucleus to the centrosome in neuronal migration. J Cell Biol 165: 709-721.

Tiveron MC, Rossel M, Moepps B, Zhang YL, Seidenfaden R, Favor J, Konig N, Cremer H. 2006. Molecular interaction between projection neuron precursors and invading interneurons via stromal-derived factor 1 (CXCL12) CXCR4 signaling in the cortical subventricular zone/ intermediate zone. J Neurosci 26: 13273-13278.

Tomioka N, Osumi N, Sato Y, Inoue T, Nakamura S, Fujisawa H, Hirata T. 2000. Neocortical origin and tangential migration of guidepost neurons in the lateral olfactory tract. J Neurosci 20: 5802-5812.

Trommsdorff M, Gotthardt M, Hiesberger T, Shelton J, Stockinger W, Nimpf J, Hammer RE, Richardson JA, Herz J. 1999. Reeler/Disabled-like disruption of neuronal migration in knockout mice lacking the VLDL receptor and ApoE receptor 2. Cell 97: 689-701.

Tsai LH, Gleeson JG. 2005. Nucleokinesis in neuronal migration. Neuron 46: 383-388.
Tsai JW, Chen Y, Kriegstein AR, Vallee RB. 2005. LIS1 RNA interference blocks neural stem cell division, morphogenesis, and motility at multiple stages. J Cell Biol 170: 935-945.

Ward ME, Jiang H, Rao Y. 2005. Regulated formation and selection of neuronal processes underlie directional guidance of neuronal migration. Mol Cell Neurosci 30: 378-387.

Wichterle H, Alvarez-Dolado M, Erskine L, Alvarez-Buylla A. 2003. Permissive corridor and diffusible gradients direct medial ganglionic eminence cell migration to the neocortex. Proc Natl Acad Sci 100: 727-732.

Wichterle H, Garcia-Verdugo JM, Alvarez-Buylla A. 1997. Direct evidence for homotypic, glia-independent neuronal migration. Neuron 18: 779-791.

Wray S. 2002. Molecular mechanisms for migration of placodally derived GnRH neurons. Chem Senses 27: 569-572.

Xie Z, Sanada K, Samuels BA, Shih H, Tsai LH. 2003. Serine 732 phosphorylation of FAK by Cdk5 is important for microtubule organization, nuclear movement, and neuronal migration. Cell 114: 469-482.

Yau HJ, Wang HF, Lai C, Liu FC. 2003. Neural development of the neuregulin receptor ErbB4 in the cerebral cortex and the hippocampus: Preferential expression by interneurons tangentially migrating from the ganglionic eminences. Cereb Cortex 13: 252-264.

Yee KT, Simon HH, Tessier-Lavigne M, O’Leary DM. 1999. Extension of long leading processes and neuronal migration in the mammalian brain directed by the chemoattractant netrin-1. Neuron 24: 607-622.

Ying G, Wu S, Hou R, Huang W, Capecchi MR, Wu Q. 2009. The protocadherin gene Celsr3 is required for interneuron migration in the mouse forebrain. Mol Cell Biol 29: 3045-3061.

Yokota Y, Gashghaei HT, Han C, Watson H, Campbell KJ, Anton ES. 2007. Radial glial dependent and independent dynamics of interneuronal migration in the developing cerebral cortex. PLoS One 2: e794.

Yoneshima H, Nagata E, Matsumoto M, Yamada M, Nakajima K, Miyata T, Ogawa M, Mikoshiba K. 1997. A novel neurological mutant mouse, yotari, which exhibits reeler-like phenotype but expresses CR-50 antigen/ reelin. Neurosci Res 29: 217-223.

Yoshida M, Assimacopoulos S, Jones KR, Grove EA. 2006. Massive loss of Cajal-Retzius cells does not disrupt neocortical layer order. Development 133: 537-545. 


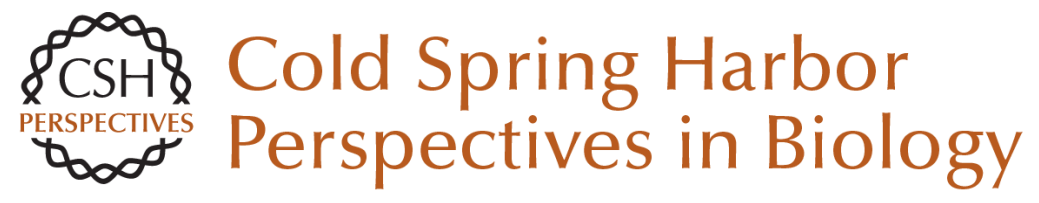

\section{Guiding Neuronal Cell Migrations}

Oscar Marín, Manuel Valiente, Xuecai Ge and Li-Huei Tsai

Cold Spring Harb Perspect Biol 2010; doi: 10.1101/cshperspect.a001834 originally published online January 13, 2010

\section{Subject Collection Neuronal Guidance}

Mechanisms and Molecules of Neuronal Wiring: A Primer

Alex L. Kolodkin and Marc Tessier-Lavigne

Guidance Molecules in Axon Pruning and Cell

Death

Pierre Vanderhaeghen and Hwai-Jong Cheng

Initiating and Growing an Axon

F. Polleux and William Snider

Navigating Intermediate Targets: The Nervous System Midline

Barry J. Dickson and Yimin Zou

Cellular Strategies of Axonal Pathfinding

Jonathan Raper and Carol Mason

Guidance Molecules in Axon Regeneration

Roman J. Giger, Edmund R. Hollis II and Mark H. Tuszynski

Signaling from Axon Guidance Receptors Greg J. Bashaw and Rüdiger Klein

Visual Map Development: Bidirectional Signaling, Bifunctional Guidance Molecules, and Competition

David A. Feldheim and Dennis D. M. O'Leary
Wiring the Brain: The Biology of Neuronal

Guidance

Alain Chédotal and Linda J. Richards

Guidance Molecules in Synapse Formation and

Plasticity Kang Shen and Christopher W. Cowan

The Growth Cone Cytoskeleton in Axon

Outgrowth and Guidance

Erik W. Dent, Stephanie L. Gupton and Frank B. Gertler

Topographic Mapping--The Olfactory System Takeshi Imai, Hitoshi Sakano and Leslie B. Vosshall

Self-avoidance and Tiling: Mechanisms of

Dendrite and Axon Spacing Wesley B. Grueber and Alvaro Sagasti

Trafficking Guidance Receptors Bettina Winckler and Ira Mellman

Axon Guidance Molecules in Vascular Patterning Ralf H. Adams and Anne Eichmann

Human Genetic Disorders of Axon Guidance Elizabeth C. Engle

For additional articles in this collection, see http://cshperspectives.cshlp.org/cgi/collection/

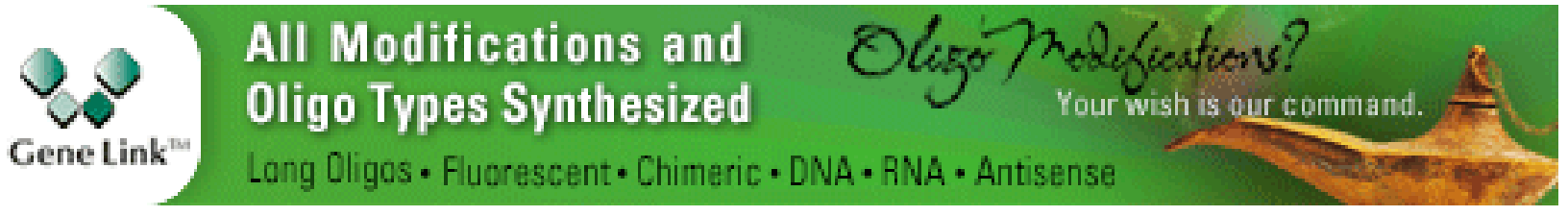

Copyright @ 2010 Cold Spring Harbor Laboratory Press; all rights reserved 